\title{
Connectives and discourse markers in Ancient Greek
}

\section{The diachrony of atár from Homeric Greek to Classical Attic}

\author{
Guglielmo Inglese*
}

Università degli Studi di Pavia/Università degli Studi di Bergamo guglielmo.ingleseo1@ateneopv.it

\begin{abstract}
The Ancient Greek particle atár has been described as a connective device that encodes either an adversative or a progressive relation between sentences. The purpose of this paper is to revise the description of this particle by framing its analysis within a consistent and theoretically up-to-date model of clause linkage and discourse structure. Starting from previous findings on the function of atár in Homer, I undertake a corpus analysis of atár in Euripides and Aristophanes. This analysis reveals differences in usage at different stages of the language that have been previously neglected. Whereas in Homer, atár largely behaves as a connective and encodes a semantic relation of oppositive contrast between sentences, in later texts it rather behaves as a discourse marker and contributes to the management of both thematic continuity and interactional practices. These differences point to a specific diachronic path of grammaticalization that accounts for the changes undergone by atár.
\end{abstract}

\section{Keywords}

Ancient Greek - connectives - discourse markers - grammaticalization - conversation analysis

* I would like to thank Silvia Luraghi, Caterina Mauri, Nicolas Bertrand, and Luigi Battezzato, as well as an anonymous reviewer, for sharing with me most useful comments and observations on earlier drafts of this paper. Needlessly to say, all remaining errors are my own.

(C) GUGLIELMO INGLESE, 2018 DOI: $10.1163 / 15699846-01801003$

This is an open access article distributed under the terms of the prevailing CC-BY-NC license at the time of publication. 
In this paper, I propose a new descriptive framework for the particle atár in Ancient Greek and provide a detailed account of its functions in a diachronic corpus with texts ranging from Homeric to Classical Greek. The aim of the work is twofold. In the first place, I provide a new synchronic analysis of the function of atár in Ancient Greek. In reference works, atár has been described as a particle whose function is to establish adversative or progressive relations between sentences. My first aim is to give a more accurate, corpus-based, and theoretically updated description of atár, exploiting the notions of connective (cf. Halliday \& Hasan 1976, Mauri 2008, Mauri \& van der Auwera 2012) and of discourse marker (cf. Schiffrin 2003, Blackemore 2006, Diewald 2011, Heine 2013). These two notions also help shed light on the differences in usage between different periods of the language. In addition, my analysis is framed within a consistent model of discourse structure (Kroon 1995). The second aim of the paper is to account for these differences in diachronic terms. It is now commonly agreed upon that discourse markers can develop out of several lexical sources following specific paths of grammaticalization (cf. Traugott 1995, 2010a; Giacalone Ramat \& Mauri 2009; Diewald 2011; Heine 2013), and this also applies to Greek particles (Allan 2017a). I illustrate how such a diachronic development might have taken place in the case of atár and discuss a number of critical contexts out of which the new functions have arisen, showing how dialogicity plays a key role in explaining such a change (Traugott 2010b).

The paper is organized as follows: in the second section, I briefly recapitulate the traditional analysis of atár. In the third section, I discuss the theoretical foundations of this work, and introduce the notions of connective and of discourse marker. In Section 4, I provide an outline of the function of atár in Homeric Greek, and then, in Section 5, I address the issue of the function of atár in Classical Greek. Finally, in Section 6, I discuss the diachronic interpretation of the data. Section 7 contains a concluding summary.

The form atár is a Greek formation, possibly formed within the Ionic dialect, but based on inherited Indo-European material (Ruijgh 1957: 43). According to Beekes (2010: 162), the form goes back to PIE ${ }^{*} h_{2}$ et (cf. Lat. at, Got. appan), combined with ára, itself the outcome of PIE ${ }^{*} h_{2}(e) r$ (cf. Lith. ir , Latv. ir). ${ }^{1}$ It

1 Following Beekes (2010), I assume the forms atár and autár to be etymologically unrelated. 
first occurs in Homer and then sporadically in early Ionic prose. Though more frequent than in Ionic prose, in Attic literature of the classical age atár basically occurs only in the works of Euripides and Aristophanes, and to a much lesser extent in Plato; however, it is carefully avoided by historians and orators, with the exception of Xenophon. This peculiar distribution made Denniston (1954: 51) propose a vernacular origin of the form, socially marked as belonging to the lower register. Besides late sporadic usages, literary prose texts of Hellenistic age show no occurrence of atár, suggesting it had dropped out of use by that time. $^{2}$

Concerning its classification, atár has been traditionally considered a particle, that is, a word "expressing a mode of thought, considered either in isolation or in relation to another thought, or a mood of emotion" (Denniston 1954: xxxvi; see also Allan 2017b: 280). The linguistic reality of and the theoretical need for a 'particle' category have been persuasively called into question by Duhoux (2003), to which I refer for further discussion. I follow here Duhoux's approach, and employ the term 'particle' only as a general cover term to refer to atár, without any implication as to its linguistic status.

According to Schwyzer \& Debrunner (1950: 559), Denniston (1954: 51-54), Chantraine (1968: 132), Ruijgh (1971: 197), and Crespo et al. (2003: 349), among others, atár is a linking device that can occur either in an 'adversative' or a 'progressive' function. In its adversative function, atár encodes a semantic contrast between two sentences, whereas in its progressive function no contrast is intended, and atár behaves like a mere combining device. This interpretation seems, however, too sketchy, as it overlooks some crucial points. First, no difference has been pointed out in the use of atár at different diachronic stages of the language, or in texts belonging to different genres. Second, this poly-

Additionally, Inglese (2017) shows how the two particles should be kept functionally distinct, at least in Homeric Greek (see further Bonifazi 2012: $212 \mathrm{fn}$. 84). Therefore, the present analysis does not overlap with previous works on the function of autár (cf. Bonifazi 2012).

2 It must be stressed that this picture on the distribution of atár is somewhat oversimplified. As the evidence in the $T L G$ shows, occurrences of atár are also documented in fragmentary texts from the Classical period, with a sizable number of occurrences from comic authors. Later on, the particle is sporadically attested in literary texts, both in poetry and in prose, up to the 13th century AD. Though a detailed analysis of the behavior of atár in post-Classical texts lies beyond the scope of this paper, it is interesting to observe that many of the occurrences are confined to specific textual genres, including epic poetry and scientific prose. Interestingly, the particle is virtually unattested in non-literary sources, such as inscriptions and papyri, thus bearing further evidence for its eventual demise after the Classical age. 
semy account lacks an explanation as to how these two functions are related, either in synchrony or in diachrony. Besides the attempt by Ruijgh (1971: 198) to distinguish between an allegedly primary adversative function from a secondary progressive one, only Humbert (1960) reasonably argues for a clear-cut distinction between the two. For Humbert, the basic meaning of atár is the 'progressive' one, from which the 'adversative' meaning is naturally derived, since "a new object is likely to be opposed to already known objects" (Humbert 196o: 584 , transl. mine).

3

Connectives, discourse markers, and discourse structure

In this section, I illustrate the theoretical background of my analysis. The behavior of particles has always puzzled scholars, and most traditional approaches to the subject fail in providing a satisfactory account of the real usage of these linguistic items. Most studies focus on clausal linkage only, while neglecting to consider the overall discourse structure. In this work, I frame the description of atár within a consistent model of discourse structure (Kroon 1995), and exploit the notions of connective and discourse marker.

Connectives have been thoroughly investigated by Mauri (2008) in her typological work on coordination strategies. For Mauri, connectives are defined as linguistic items encoding a coordination relationship, i.e. "a relation established between functionally equivalent States of Affairs (SoAs), that is, SoAs which have the same semantic function, autonomous cognitive profiles, and are both coded by utterances characterized by the presence of some illocutionary force" (Mauri 2008: 41). Mauri discusses three semantic types of coordination relations: combination, contrast, and alternative. Since atár has traditionally been described as an adversative particle, I take the contrast relation to be most relevant here. According to Mauri (2008: 121-124), who relies on a wealth of previous scholarship on adversativity (see also Kroon 1995: ch. 9; Allan 2017b: 28o-283), languages attest to three types of contrast: (a) oppositive contrast, which SoAs are related to only by virtue of their being different (this case being very close to combination); (b) corrective contrast, in which the propositional content of the first utterance is negated and replaced by the content of the second one, and (c) counterexpectative contrast, in which the second utterance negates an inference or an expectation drawn from the first one. The three types are exemplified in (1):

(1) a. Oppositive

I bought a pair of shoes whereas Sue found a nice skirt 


\section{b. Corrective}

Peter is not studying in his room but he is playing in the garden

c. Counterexpectative John is tall but he's no good at basketball

The three semantic types of contrast relations illustrated in (1) are not unrelated. Based on the evaluation of a representative cross-linguistic sample, Mauri (2008) has shown that these functions can be arranged into the following conceptual space, onto which language-specific semantic maps are mapped:

oppositive $>$ corrective $>$ counterexpectative

The semantic map model enables us to make predictions about which patterns of polysemy are expected to occur in the languages of the world. Such predictions are based on the assumption that polysemous linguistic items can only encode meanings that are contiguous in the conceptual space (Croft 2003: 133-138; see further van der Auwera 2013). Crucially in our case, we expect that a connective cannot encode oppositive and counterexpectative contrast unless it also encodes corrective contrast, because the latter occupies the central area of the conceptual space. It must be stressed that not all functions displayed by connectives should be given equal prominence. As Sweetser (1990: 76) and Mauri \& van der Auwera (2012) argue, the role of pragmatics in determining the function of connectives should not be underestimated. Indeed, it is often the case that connectives feature only a single core semantic value from which related meanings can be pragmatically derived in specific discourse contexts (for a useful summary on monosemy vs. polysemy approaches in describing the function of particles, see also Allan 2017b: $276-$ 280).

The notion of discourse marker (henceforth DM) has been refined in the last decades. Despite the wealth of recent contributions in the field, there is still no unanimous agreement on what discourse markers are and how they work, as the variation in the terminology employed suggests (e.g. Schiffrin 2003 'discourse markers'; Blakemore 2006 'discourse connectives'). I summarize here the mainstream position on the subject, and refer to Schiffrin (2003), Blakemore (2006), Diewald (2011), and Fedriani \& Sansò (2017) for a detailed discussion of theoretical and methodological approaches to the study of DMs. Broadly speaking, D Ms formally belong to different word classes, such as adverbs (however), prepositional phrases (after all), verbal phrases (I mean, listen). Most importantly here, the class of DM includes connectives (and, or, but) as well. From a diachronic standpoint, this heterogeneity reflects the different lexical sources that can give rise to DMS. 
Functionally, DMs contribute to managing a wide range of functions. Schiffrin (2003: 71) defines DMs as polyfunctional items that work on the social and the expressive level of discourse and conversation, and on the textual level, i.e. the organization and management of coherent sequences of utterances, among other things. This last function has been identified since Halliday \& Hasan (1976), who argue that connective items, including coordinators, are employed to establish coherence and cohesion relations in texts. In other words, as Kroon puts it, DMs "[are] involved in signaling the coherence of a stretch of discourse" (Kroon 1995: 58). As Drummen (2009: 135-138) points out, the main function of DMs is to constrain the hearer's interpretation of coherence relationships already inferable from the context. Hence, the use of DMs is non-obligatory.

In order to show how connectives and DMs interact in shaping discourse, I adopt here Kroon's (1995) model of discourse structure. According to Kroon, discourse can be conceived as a layered structure, in which structural and semantic relationships can be established at various levels (see Allan 2017a and 2017 b for a similar approach). In particular, Kroon (1995: $69 \mathrm{ff}$.) individuates three distinct layers of discourse. The most basic level is the 'representational' level, which deals with the encoding of propositional content. At this level, semantic relationships between SoAs are established. The second one, the 'presentational' level, deals with the organization of semantic content and with the thematic structuring between conversational moves within a speaker's turn. Relationships established at this level are labelled 'rhetorical'. Finally, the 'interactional' level deals with conversational aspects of communication, including the management of turn-taking. Within this model, connectives as defined by Mauri (2008) operate at the representational level alone, as Kroon herself observes (1995: 69). In modern Indo-European (IE) languages, connectives are usually fully grammaticalized as coordinative conjunctions, and their occurrence is limited to specific syntactic environments. ${ }^{3}$ Conversely, DMs generally act both at the presentational and at the interactional levels as they operate on the local and global coherence of texts and on the management of conversation. Crucially, one must keep in mind that connectives can be used as DMs in certain contexts, while at the same time retaining their basic function as connectives elsewhere. The need to keep the two functions distinct cannot be overestimated, since semantic clausal combining and discourse linkage should not be conceived as parallel and structurally equal phenomena (Blühdorn 2008). Therefore, in our texts, atár can in principle be shown to function either as a connective or as a DM.

3 For a general overview on coordination strategies in ancient IE languages, see also Viti (2008). 


\section{$4 \quad$ The particle atár in Homeric Greek}

In this section, I summarize the results of my previous corpus-based analysis of the function of atár in Homeric Greek (Inglese 2017). Drawing on an analysis of all the occurrences of atár in Homer, I have suggested keeping atár distinct from autár on functional grounds. The former is a connective that works at the representational level of discourse since it generally connects equivalent SoAs in accordance with the criteria discussed by Mauri (2008), whereas the latter behaves as a discourse marker and contributes to the managing of topic continuity in discourse. In addition, atár responds positively to the syntactic test proposed by Dik (1968) for the identification of coordinative conjunctions. The fact that it never occurs in combination with other coordinators must be taken as evidence that atár is a coordinator itself. Finally, unlike autár, atár occasionally connects noun or adverbial phrases (e.g. Hom. Od. 8.320, Hom. Il. 2.214). Notably, this complies with the possibility of connectives to occur at the phrase level (cf. Haspelmath 2013), which is an environment normally unavailable to DMs. The connective function of atár is exemplified in (2):

(2) hoi d' óte dế $r^{\prime}$ es khôron héna DEM.NOM.PL PTC when PTC PTC to land:ACC one:ACC ksunióntes híkonto, sún $r^{\prime}$ ébalon gather:PRS.PTCP.NOM.PL go:PRS.3PL together PTC throw:AOR.3PL rinoús, sùn d' énkhea kai méne' shield:ACC.PL together PTC spear:ACC.PL and strength:ACC.PL andrôn khalkeothōrékōn atàr aspídes man:GEN.PL in.bronzed.armor:GEN.PL CONN shield(F):NOM.PL omphalóessai éplènt' allélêosi bossy:NOM.PL.F fill:AOR.M/P.3PL each.other:DAT.PL 'When they came gathering in the same point, they dashed the spears and the strengths of men in bronzed armors together: the bossed shields clashed against each other.' (Hom. Il. 4.446-449)

Discussing example (2), I have argued that atár encodes an oppositive contrast relation as defined by Mauri (2008: 121), as the two sentences are contrasted only by virtue of their encoding different SoAs. Occurrences that feature a counterexpectative contrast, traditionally labeled 'strong adversative' function, are also attested in the corpus, as in (3): 
(3) $\hat{e}$ rá tís esti kai ein Aïdao dómoisi PTC PTC INDF.NOM be:PRS.3SG also in Hades:GEN house:DAT.PL psukhè kai eidolon atár phrénes oukéni pámpan soul:NOM and image:NOM CONN hearth:NOM.PL not inside at.all 'Oh, wonder! Even in the house of Hades there is left something, a soul and an image, but there is no more life in it.' (Il. 23.104-105)

In example (3), atár can be conceived as encoding a counterexpectative relation, as Denniston (1954: 51) suggests. However, describing atár as encoding both oppositive and counterexpectative contrast would lead to a cross-linguistically implausible semantic map, since in Homer no occurrence of atár encoding corrective contrast can be found. Therefore, I have argued that a counterexpectative reading is only pragmatically triggered by specific contextual features. For instance, in (3) the semantic opposition between psukh $\grave{e}$ kai eídōlon 'a soul and an image' and phrénes 'life' on the one hand, stressed by the contrastive topic position occupied by the latter, and the presence of the negation ouk on the other hand can be responsible for the inference of a counterexpectative relation between the two sentences. Oppositive contrast should be taken as the semantic core of the connective, as opposed to the contextually derived counterexpectative contrast function for the following reasons: first, oppositive contrast seems cognitively less complex than counterexpectative contrast. Whereas it is relatively easy for speakers to infer counterexpectative relations out of oppositive ones, as Humbert (1960: 584 ) points out, the reverse process seems to be less straightforward. Second, in Homer an oppositive contrast reading of atár is quantitatively prominent, whereas the counterexpectative reading is rather marginal and only available when atár co-occurs with other contextual cues of strong adversativity, as in (3).

By virtue of its oppositive value, atár is also employed as a thematic boundary marker. This is hardly surprising: Mauri herself observes that oppositive connectives such as Polish $a$ 'and, but' tend to be used in contexts of thematic discontinuity. Given this function, atár often correlates with the introduction of preverbal contrastive topics (cf. Matić 2003). ${ }^{4}$ More precisely, within a discourse stretch that features a pair of topical referents, atár establishes a

4 I cannot go into further detail on the issue of information structure in Ancient Greek. For a general discussion on the notion of topic, see, among others, Gundel \& Fretheim (2006). Information structure in Ancient Greek has been fully investigated by Dik (1995, 2007), Matić (2003), Bertrand (2010), and Allan (2014). In Inglese (2017), I have relied on the parameters discussed by these authors to evaluate the topical status of NPs following atár. 
coordination relationship of oppositive contrast and hence favors the introduction of the second referent as a contrastive topic. This is an instance of what Givón (1983: 9) calls a local switch-reference in the 'participant/topic continuity' domain. The locality of the switch-reference is proven by examples like (4):

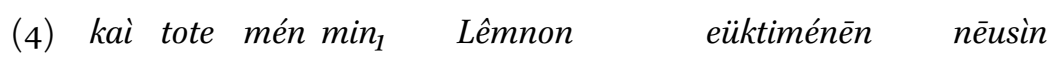
and then PTC 3SG.ACC Lemnos(F):ACC well.built:ACC.F ship:DAT.PL ágōn, atàr huiòs $s_{2}$ Iésonos ônon lead:PRS.PTCP.NOM CONN son:NOM of.Iason:NOM price:ACC édōke. keîthen dè kseînós $\min _{1}$ give:AOR.3SG from.there PTC stranger:NOM 3 SG.ACC elúsato free:AOR.M/P.2SG 'And then (Achilles) sold him (Lykaon) in strong-founded Lemnos, carrying him there by ship, and the son of Jason bought him. From there a stranger freed him.' (Hom. Il. 21.40-42)

In (4), the discourse topics previously established are Lykaon, who is encoded by the anaphoric pronoun min 'him' in the first sentence, and Achilles, who is the subject of the first sentence and is not overtly marked. These topics are temporarily deactivated by the introduction of the new referent, huiòs Iếsonos 'the son of Jason', which is a new preverbal sentence topic (Matić 2003: 589, Allan 2014: 189). However, this thematic boundary signaled by atár does not entail a new orientation in discourse, as the new topic does not achieve the role of new discourse topic, i.e. it displays low discourse persistence (Givón 1983). This is proven by the fact that the following light anaphoric pronoun min does not refer back to the son of Iones, which is the last accessible topical referent, but directly to the previously established discourse topic, Lykaon.

Though the majority of the occurrences of atár in Homer fall into this description, a handful of occurrences is not entirely consistent with this account. I provide two significant counterexamples in (5a) and (5b).

(5) a. andra thnētòn eónta pálai peprōménon man:ACC mortal:ACC be:PRS.PTCP.ACC long assigned:ACC aísēi àps ethéleis thanátoio dusēkhéos fate:DAT back wish:PRS.2SG death:GEN ill.sounding:GEN eksanalûsai; édr': atár oú toi pántes release:AOR.INF do:PRS.IMP.2SG CONN not 2SG.DAT all:NOM.PL epainéomen theoi álloi praise:PRS.1PL god:NOM.PL other:NOM.PL 
'A mortal man, long doomed by his destiny, do you wish to release him from ill-sounding death? Do it. But not all of us other gods will praise you.' (Hom. Il. 16.441-443)

b. $\hat{e}$ onósasth' hóti moi Kronídēs

INT complain:AOR.M/P.2PL that 1SG.DAT son.of.Chronos:NOM Zeùs álge' édōke paîd' olésai Zeus:NOM pain:ACC.PL give:AOR.3SG son:ACC destroy:AOR.INF tòn áriston? atàr gnốsesthe kaì úmmes ART.ACC best:ACC CONN know:FUT.M/P.2PL also 2SG.PL.NOM 'Do you complain that Zeus son of Chronos has given me sufferings, that he killed my most noble son? But you will know it yourselves.' (Hom. Il. 24.241-242)

In both (5a) and (5b), a connective interpretation of atár is ruled out by the fact that the utterances linked by the particle do not share the same illocutionary force, thus going against Mauri's (2008) criteria. In (5a), atár signals the boundary between an order and an assertion, whereas in $(5 \mathrm{~b})$ it relates an assertion to a question, the latter overtly marked by the interrogative particle $\hat{e}$. Remarkably, in both cases atár occurs in dialogues, in which it seemingly behaves as a strong thematic boundary maker, as I argue in Section 5.3.2. The question that I address in the next sections is how to capture the function of atár in instances such as $(5 a)$ and $(5 b)$, and how this relates to the basic connective function detected in Inglese (2017).

\section{$5 \quad$ The particle atár in Classical Greek}

In this section, I analyze the behavior of atár in a corpus consisting of the works of Aristophanes and Euripides. Note that in the remainder of this paper, when I refer to Classical Greek I essentially refer to Classical Attic. First, in Section 5.1, I provide some methodological remarks, and then I proceed to a quantitative (Section 5.2) and qualitative (Section 5.3) analysis of the data. Finally, in Section 5.4, I present a unified account of the use of atár in Classical Greek.

\subsection{Methodological remarks}

The reason to restrict the corpus to Attic drama for this study is twofold. In the first place, this is the most representative corpus for the investigation of the particle, since in Attic drama one finds the majority of the occurrences of atár 
in post-Homeric Greek. In the second place, the corpus is constituted by theatrical texts, the language of which is intended to imitate real-life conversation. Indeed, even though the language of theater must undergo metrical restrictions and fails to show spoken phenomena such as false starts and overlappings, it is nonetheless a 'quasi-spoken' stylized language, as it calls upon the hearer's pragmatic and conversational knowledge in order to understand the ongoing stage performance (Dik 2007: 7). These factors contribute to making this corpus the best candidate for investigating discourse and pragmatic phenomena in Ancient Greek. ${ }^{5}$

My corpus includes the works by Aristophanes and Euripides. I exclude Aeschylus' and Sophocles' works because they feature only a handful of occurrences of atár, one and three respectively. Moreover, I exclude fragmentary texts from the corpus, since in these texts one often lacks the discourse context needed for a correct pragmatic interpretation of the utterances (Dik 2007: 5). It should be stressed that, although I acknowledge the difference in genre between Aristophanes and Euripides, I consider them to some extent equally reliable sources for the study of the spoken language. Indeed, even though comedy displays a greater linguistic realism, as it matches more closely the morphosyntactic and lexical features of Attic (Willi 2002: 18), it must be kept in mind that comedy implies a rather non-standard usage of spoken language (Dik 2007). In particular, as Bain (1977) remarks, the comic dialogue constitutes by no means a better imitation of spoken Attic than tragedy, because comedy exploits a wide range of non-conventional linguistic resources to move the audience to laughter, such as puns and parody, as well as making extensive use of ruptures of the dramatic illusion.

\subsection{Quantitative analysis}

Table 1 shows quantitative data extracted from the corpus regarding the frequency of atár and its main collocations. ${ }^{6}$ Overall, atár shows a token fre-

5 To be sure, atár also occurs in Herodotus' and Plato's works. However, in these authors the occurrences of atár are extremely scarce with respect to the entire size of the corpus, so the data is quantitatively not comparable to Attic drama. In addition, even though Plato might in principle provide a good candidate for the investigation of spoken Attic (cf. Horrocks 2010: 69 ), his works differ radically from drama in style, purpose, and use of discourse strategies. Based on these observations and for reasons of space, Herodotus and Plato are left out of consideration for the purposes of this paper.

6 Data comes from the $T L G$. Collocations have been analyzed through the software AntConc (http://www.laurenceanthony.net/software.html). 
TABLE 1 Frequency and collocations of atár and allá

\begin{tabular}{|c|c|c|c|c|c|c|c|}
\hline \multirow[t]{3}{*}{ atár } & Euripides & 33 & & allá & Euripides & 868 & \\
\hline & Aristophanes & 47 & & & Aristophanes & 1068 & \\
\hline & Total & 80 & $100 \%$ & & Total & 1936 & $100 \%$ \\
\hline \multirow[t]{3}{*}{ atàr $[\ldots]$ ge } & Euripides & 7 & $21 \%$ & allà $[\ldots] g e$ & Euripides & 5 & o,6\% \\
\hline & Aristophanes & 11 & $26 \%$ & & Aristophanes & 25 & $2,3 \%$ \\
\hline & Total & 18 & $22 \%$ & & Total & $3^{\circ}$ & $1,5 \%$ \\
\hline \multirow[t]{3}{*}{ atàr tís } & Euripides & 11 & $35 \%$ & allà tís & Euripides & 5 & o,6\% \\
\hline & Aristophanes & 10 & $21 \%$ & & Aristophanes & 13 & $1,2 \%$ \\
\hline & Total & 21 & $26 \%$ & & Total & 18 & $0,9 \%$ \\
\hline
\end{tabular}

quency of 33 in Euripides and 47 in Aristophanes, which is strikingly low as compared to other clause-linking devices (e.g. allá 1936 and dé 6o36). Another interesting parameter is the collocational behavior of atár, i.e. the set of its most recurrent syntagmatic associations. Since atár has been traditionally described as an adversative coordinator, in Table 1 I illustrate its collocational behavior as compared to allá, which is commonly held to be the main adversative connective in Ancient Greek (Drummen 2009, Lühr \& Zeilfelder 2011: 118, Allan 2017b: 283-292).

Two main collocations of atár emerge from the corpus, which together cover almost half of the attestations. These are the construction with the interrogative pronoun tís 'who, what' in direct questions, and the construction involving the enclitic emphatic particle ge in assertions. These patterns cover respectively $22 \%$ and $26 \%$ of the occurrences. Interestingly, these two patterns are by no means relevant for allá, as they cover respectively 1,5\% and o,9\% of the total. Moreover, atár and allá also differ in their distribution in relation to conversational turns. In my corpus, atár consistently occurs within conversational turns, with only one instance of turn-initial position (Eur. Med. 8o), whereas turn-initial allá displays a much wider distribution, as Drummen (2009:142 ff.) has shown. This different distributional behavior points to a difference in function between atár and allá.

Quantitative data allows for a few preliminary remarks on the diachrony of the particle. Despite being relatively well attested in Classical Greek, the overall frequency of atár is lower than other particles. Keeping in mind its already low frequency in Homeric Greek and its later disappearance from the language, it seems that Attic drama reflects a stage in which this form was slowly dropping out of use. This view is supported by the collocational patterns illustrated in Table 1. In Homer, atár shows no significant collocational pattern 
besides the aforementioned construction with ge, which covers only $14 \%$ of the occurrences. This means that atár is basically freely used in Homer, as data on its low formularity confirms (Ruijgh 1957). Conversely, in Attic drama atár shows strong signs of idiomatization. I return to these observations in Section 6.

\subsection{Qualitative analysis}

In this section, I provide a synchronic account of the functions of atár in Aristophanes and Euripides. I describe various kinds of context in which atár occurs in order to investigate its function, exploiting the theoretical notions introduced in Section 3 .

\subsubsection{Atár as a connective}

As argued in Section 4, in Homer atár largely behaves as a connective that acts at the representational level of discourse, where it establishes coordination relations of oppositive contrast (Mauri 2008). In my corpus, only three occurrences of atár follow this pattern (Eur., Hipp. 728; Eur., Tr. 344 and 416), as exemplified in (6):

(6) Hếphaiste, daidoukheîs mèn en gámois Hephaestus:voc bring.flames:PRS.2SG PTC in marriage:DAT.PL brotôn atàr lugrán ge tênd' anaithússeis mortal:GEN.PL DM woeful:ACC.F PTC DEM.ACC.F light:PRS.2SG phlóga éksō te megálōn elpídōn torch(F):ACC beyond and big:GEN.PL hope:GEN.PL

Hecuba: 'Hephaestus, you bring the flame to the marriages of men: now it's a woeful torch that you light, beyond my greatest hopes.'

(Eur., Tr. 343-345)

In (6), as well as in the other two cases, atár functions as an oppositive connective, and more importantly, it always occurs in a correlative construction with mén, which constitutes a rather frequent structure already in Homer (Inglese 2017), as shown in (7). When occurring in such correlative structures, atár can be described as a 'complementation device' (Bakker 1993: 298), as it indicates the closure of a bipartite thematic section introduced by mén.
(7) ei mén k' aûthi ménōn
Trôón
pólin
if PTC IRR here stay:PRS.PTCP.NOM Troians:GEN.PL city:ACC
amphimákhōmai óleto mén moi
destroy:PRS.SUBJ.M/P.1SG perish:AOR.M/P.3SG PTC 1SG.DAT 
nóstos atàr kléos áphthiton éstai

return:NOM CONN glory(N):NOM everlasting:NOM.N be:FUT.M/P.3SG

'If I stay here and destroy the city of the Troians, I will not return home, but the glory will be everlasting.' (Hom. Il. 9.412-413)

A crucial difference between (6) and (7) lies in the fact that, in Classical Greek, atár does not correlate with the introduction of contrastive topics. Instead, in (6) atár is followed by a contrastive focus that is reinforced by the emphatic contrastive particle ge and by a non-canonical word order, with the fronting of the adjective lugrán 'woeful'. Note that example (6) could also be read as an instance of counterexpectative contrast, but I maintain that even in (6), it is better to interpret the counterexpectative reading as pragmatically inferred, for the reasons discussed in Section 4. First, a counterexpectative reading is triggered by the presence of the contrastive focus. And second, this reading is easily inferable from the semantic contrast established between the two SoAs, as they compare the habitual behavior of the god with his unexpected behavior in the situational context described in the second utterance.

\subsubsection{Atár as a discourse marker}

To begin with, let us discuss a number of occurrences in which a connective reading of atár is necessarily ruled out. These are the cases in which atár links two utterances with different illocutionary force, thus violating the definitional criteria set out by Mauri (2008). In the majority of the cases these are assertions followed by questions, but transitions from a question to an assertion (e.g. Eur., Bacch. 248) and from an assertion to an order (e.g. Ar., Vesp. 28) are attested as well. In these occurrences, atár can be shown to operate as a DM, and its function is better understood in the light of conversation analysis (Levinson 1983, Sidnell 2010; see also van Emde Boas 2017 on conversation analysis and Greek drama), exploiting the notions of turn and conversational move. I take the turn as the primary unit of a conversational exchange (Sacks et al. 1974), which in our theatrical texts roughly corresponds to the lines of a character. Each turn is further analyzable as a hierarchic structure of conversational moves, i.e. communicative acts conveying specific communicative intentions and entailing expected reactions (Andorno 2003: 162-163). It must be stressed that conversational moves do not always overlap with linguistic acts as defined by Searle (1969), since conversational moves represent a more nuanced description of interactional practices.

Let us start by considering example (8): 


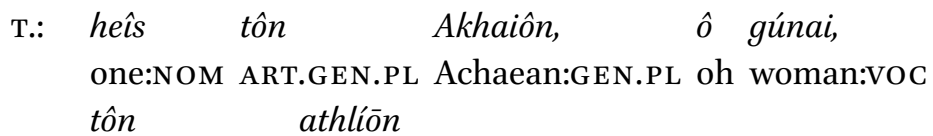

ART.GEN.PL wrecked:GEN.PL

$\begin{array}{llll}\text { H.: } & \text { ou } t^{\prime} \text { ára } s^{\prime} \quad \text { Helénēn ei stugeîs } \\ & \text { NEG PTC PTC 2SG.NOM Helen:ACC if } & \text { hate:PRS.2SG } \\ \text { thaumastéon. atàr tís } & e \hat{\imath} & \text { póthen? } \\ \text { admirable:ACC DM INT.NOM be:PRS.2SG whence }\end{array}$

Teucros: 'I am one of the Achaeans, woman, of the wrecked ones.' Helen: 'No wonder then if you hate Helen. But whence do you come?' (Eur., Hel. 84-87)

The dialogue in (8) constitutes a good exemplification of atár's most frequent function in Attic drama. In (8), a dialogue between Helen and Teucros is staged. In the first line, Teucros answers a question previously asked by Helen, who in her turn responds with a brief comment before asking another question herself. This conversational pattern frequently occurs in the corpus and can be sketched as follows. Character A ends his/her turn with a given conversational move. Character B responds with what I call a 'comment move', which is irrelevant from an informative point of view and still preserves the discourse topic introduced by A in his/her turn. Only then does character B utter within his/her turn a second move, with which s/he fully takes his/her turn and carries on the dialogue with a new orientation. Within this structure, the role of atár as a DM is precisely to signal the end of a backgrounded comment line and the introduction of a brand-new foregrounded line that encodes a reactive move (Kroon 1995: 366).

Clearly, in structures such as (8), atár does not act as an oppositive connective on the representational level, as one cannot semantically coordinate an assertion and a question. In discourse terms, the function of atár is rather fuzzy. On the one hand, it structures the thematic transition between moves within a single turn, thus working at the presentational level. On the other hand, the move introduced by atár constitutes a reaction to what was previously said by speaker A and emphasizes the achieved possession of the turn by speaker B, so that atár displays an interactional function of sorts. This pervasive synchronic fuzziness between the two levels is not surprising (as Kroon 1995: 35 o discusses for Latin $a t$ ) and can be accounted for in diachronic terms, as I argue in Section 6.

To support this reading of atár as a foregrounding D $\mathrm{M}$, let us consider various ways in which the first line of character B, that I label the 'comment move', may be interpreted as carrying backgrounded information. We begin by considering example (9): 
(9) M.: éstai; pónous gàr daímones paúsousí

be:FUT.M/P.3SG pain:ACC.PL for god:NOM.PL end:FUT.3PL mou. atàr thanónta toû $m^{\prime}$ ereîs 1SG.GEN DM die:AOR.PTCP.ACC INT.GEN 1SG.ACC say:FUT.2G pepusménē? learn:PF.PTCP.M/P.NOM.F

Menelaus: 'Be it so; the gods will indeed end my sufferings. Anyway, from whom will you tell to have received the news of my death?' (Eur., Hel. 1075-1076)

In (9), Menelaus begins his turn with a brief responsive form éstai 'be it', followed by a digressive move, whose background status is overtly marked by the digressive particle gár 'for'. The digression is then ended by atár that introduces a new reactive and foregrounded move.

The corpus attests to at least three other patterns in which the backgrounded status of the first move is evident, that is, orders given to a third character on stage, jokes, and asides. The first pattern occurs when three characters are on stage, and two of them, A and B, are talking to each other. Then, character B gives an order to a third character $\mathrm{C}$, thus breaking the dialogic channel with character A. The dialogue with A is restored by character B with an utterance introduced by atár, as in (10):

(10) S.: sigếsat, $\quad \hat{o}$ tékn', ántra d' es

be.silent:AOR.IMP.2PL oh son:ACC.PL cave(F):ACC PTC to petrērephê poímna athroîsai prospólous rocky:ACC.F herd:ACC gather:INF.AOR servant:ACC.PL keleúsate. order:AOR.IMP.2PL herd:ACC

C.: khōreît,' atàr dè tína páter, spoudè̀n proceed:PRS.IMP.2PL DM PTC INT.ACC father:VOC hurry:ACC ékheis?

have:PRS.2SG

Silenus: 'Silence, sons; give order to the servants, to gather the flocks inside the rocky cave.'

Coryphaeus: '(To the servants) Do as he says. (To Silenus) Anyway, why are you so eager, father?' (Eur., Cycl. 82-84)

The other two patterns are typical of comedy. Consider example (11): 
(11) Sc.: tautòn dúnataí soi

ART.ACC.N=Same:ACC.N mean:PRS.M/P.3SG 2SG.DAT

kárdopos Kleōnúmōi.

kneading.trough:NOM Cleonymus:DAT

St.: all' ogáth' oud' ên kárdopos

but oh=good:VOC not be:IMPF.3SG kneading.trough:NOM

Kleōnúmōi all' en thueíai strongúlèi $g^{\prime}$ àn

Cleonymus:DAT but in mortar(F):DAT round:DAT.F PTC PTC

emátteto atàr tò loipòn pôs

knead:IMPF.M/P.3SG DM ART.NOM.N rest(N):NOM how

me khrè kaleîn

1SG.ACC need:PRS.3SG call:PRS.INF

Socrates: 'For you 'kneading-trough' is the same as 'Cleonymus.'

Strepsiades: 'Good sir. Cleonymus didn't have a kneading-trough, he used to knead his bread in a round mortar! Anyway, how should I call it henceforth?' (Ar., Nub. 673-674)

In (11), Strepsiades reacts to Socrates' statement with a joke, and then changes the subject by means of a question introduced by atár. ${ }^{7}$ According to Bain (1977: 65), jokes consist of lines uttered not with the purpose of carrying on an on-stage dialogue, but rather aiming at insulting either the hearer or other characters. Remarkably, the hearer often shows no sign of having heard the joke, which is thus uttered only for the audience's sake and constitutes a rupture of the dramatic illusion. After the joke, the conversation is restored by the utterance introduced by atár, to which the hearer normally reacts.

Asides differ from jokes in that they are never heard by other characters, who are not the intended target of the utterance (Bain 1977: 15). A case in point is example (12), in which the behavior of atár is similar to (11) in that it introduces a move that restores the flow of the conversation after an interruption.

(12) H.: haksápantas eis tò

bárathron embaleîn. every:ACC.PL to ART.ACC.N abyss(N):ACC throw:AOR.INF
c.: $h \bar{e}$
glôtta
tôi
kéruki

ART.NOM.F tongue(F):NOM ART.DAT messenger:DAT

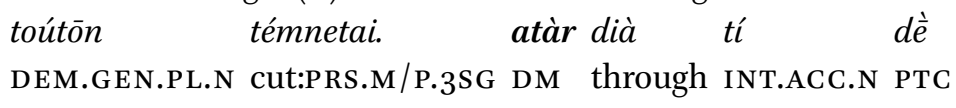

7 The line arguably contains a hint to the sexual habits of Cleonymus that were well-known to the audience (Guidorizzi \& del Corno 1996: 276). 


\section{taût' epibouleúei poieîn hèmâs?}

DEM.ACC.PL.N want:PRS.3SG do:PRS.INF 1PL.ACC

Hermes: '[Zeus wants] to throw you all down in the abyss.'

Carion: '(aside) Beware your tongue, you cursed harbinger! (to Hermes) But why would he reserve us such a treatment?'

(Ar., Pl. 1109-1112)

Example (12) raises the issue of the relationship of atár with the management of turn-taking. In fact, the line introduced by atár is the first one to be effectively heard by the hearer and thus constitutes the proper beginning of Carion's turn. The link between example (12) and such turn-initial occurrences is dealt with in more detail below. In examples (10) to (12), since the function of atár is basically to restore the dialogic channel after some kind of interruption, one can also describe it as a "POP" device, in the terminology of Slings (1997), i.e. a means of indicating a return to the main thread of a storyline, much as he suggests for allá.

I turn now to discussing a pattern in which the backgrounded nature of the move preceding atár is apparently less clear, exemplified in (13):

\begin{tabular}{|c|c|}
\hline \multirow[t]{6}{*}{ O: } & gunaîkes, \\
\hline & foreign:VOC.PL.F woman(F):VOC.PL PTC DEM.NOM.PL.N \\
\hline & Akhilléōs paidòs mélathra \\
\hline & be:PRS.3SG Achilles:GEN son:GEN roof:NOM.PL and \\
\hline & turannikai \\
\hline & royal:NOM.PL.F house(F):NOM.PL \\
\hline \multirow[t]{8}{*}{ Ch.: } & atàr dè tís \\
\hline & know:AOR.2SG DM PTC INT.NOM 2SG.NOM \\
\hline & punthánēi \\
\hline & inquire:PRS.M/P.2SG DEM.ACC.PL.N \\
\hline & Orestes: 'Foreign women, is this the house of the son of Achilles and \\
\hline & his offspring?' \\
\hline & Chorus: 'You're right. But who are you to ask this?' \\
\hline & (Eur., And. 881-883) \\
\hline
\end{tabular}

In (13), the conversational move immediately preceding atár is the answer to a direct question and updates the informational status of the current discourse. Therefore, it is hardly backgrounded or irrelevant. In these cases, the involvement of atár can be explained by reference to the notion of 'adjacency pair'. In conversation analysis, adjacency pairs are described as pairs of conversational moves, of which the first entails the uttering of the second in order 
to preserve the specific conversational patterns (Andorno 2003: 163). Under this view, in (13) the answer uttered by character $B$ is entailed by the question posed by character $\mathrm{A}$, and thereby partly falls out of control of character $\mathrm{B}$, who overtly establishes his own brand-new turn with a reactive move introduced by atár.

Besides occurring in dialogues, atár occasionally occurs in monologues, as in (14):

(14) ánoma mèn tekeîn emé, kakôs dè illegal:ACC.PL.N PTC generate:AOR.INF 1SG.ACC badly PTC gêmai patéra sòn phûnaí te marry:AOR.INF father:ACC POSS.2SG.ACC generate:AOR.INF and sé. atàr tí taûta?

2SG.ACC DM why DEM.ACC.PL.N

Jocasta: '[...] I gave birth to a forbidden child, I joined your father in wretched marriage, and I generated you. But why speak of all this?' (Eur., Phoen. 380-383)

In (14), Jocasta starts recalling her relationship with her son Oedipus, but she abruptly interrupts the narration with an utterance introduced by atár that dismisses the previous talking as nonsense. In order to understand the role of atár in (14), one should take this example as an instance of 'diaphonic' monologue (Kroon 1995: 111). Diaphony arises in monologues when a doubling of the voices occurs, such that characters address themselves as if they were external speakers. Accordingly, one can conceive the monologue in (14) as diaphonic, and the reactive move introduced by atár as uttered by an external speaker. In this case, atár acts in a fuzzy zone in which the presentational and the interactional levels partly overlap.

So far, I have discussed instances in which atár cannot behave as a connective, due to the different illocution of the utterances involved, and I have argued that atár functions rather as a foregrounding D $\mathrm{M}$. But how should we treat occurrences in which atár relates utterances with the same illocutionary force, yet in which a connective reading is not as straightforward as in (6)? Each case should be judged on its own. In a number of cases, atár behaves consistently with what I discussed for examples (8) to (13), as in (15):

(15) в.: égnōs gàr án; nûn d' oukhì gignốskeis

know:AOR.2SG PTC IRR now PTC not know:PRS.2SG

Ph.: egò̀ mà tòn Dín ou toínun, atàr

ISG.NOM yes ART.ACC.N Zeus:ACC not now DM 


dokề $\quad$ gé moi eoikénai málista
seem:PRS.3SG PTC 1SG.DAT look.like:PF.INF most
Morúkhou ságmati
Morichos:GEN coat:DAT
Bdelycleon: '[...] You would have recognized it. And now you don't!'
Philocleon: 'Yes, for Zeus sake, I can't now. Anyway, it seems to me
to look like one of Moricho's coats.' (Ar., Vesp. 1140-1142)

In (15), despite linking utterances with the same illocutionary force, atár acts as a DM, and introduces a new move that carries on the discourse after a comment move, precisely as in (8).

In most occurrences presented in this section, atár operates in a fuzzy zone between the presentational and interactional level. This fuzziness is best exemplified by the passage in (16):

(16) all' eis hápanta dustykhès éphus, páter.

but to all:ACC.PL.N unfortunate:NOM be.born:AOR.2SG father:VOC atàr s' erōtô tòn neōsti koíranon. Tí tónd' DM 2SG.ACC ask:PRS.1SG ART.ACC now leader:ACC why DEM.ACC hubrízeis patér' apostéllōn khthonós offend:PRES.2SG father:ACC send.away:PRS.PTCP.NOM land:GEN Antigone: 'But you are most unfortunate after all, father. (to Creon) And to you, our new leader, I ask this. Why do you offend my father, driving him away from his land?' (Eur., Ph. 1642-1644)

In (16), atár contributes both to the internal structuring of a single turn and to the management of the dialogic channel. On the one hand, the utterance introduced by atár opens a new thematic segment, while on the other hand, the personal pronoun $s$ ' 'you' in the second utterance explicitly signals the change of addressee in the conversational exchange.

Nevertheless, in a handful of occurrences atár exclusively acts on a single level only. In the first place, it can function as a DM at the presentational level, by marking thematic discontinuities. In these occurrences, no interactional value can be detected and diaphony seems not to be at play, as exemplified in (17):

(17) katabésomai. kaítoi tò katába go.down:FUT.M/P.1SG though ART.NOM.N descend:AOR.IMP.2SG toûto katabésomai. polloùs pánu dè DEM.NOM.N go.down:FUT.M/P.1SG much:ACC.PL PTC indeed 
eksēpátēken atàr hómōs katabếsomai

deceive:PF.3SG DM alike go.down:FUT.M/P.1SG

Bdelycleon: 'I will go down. Even if this 'descent' has done no good to others, indeed. But, I will go down nonetheless.' (Ar., Vesp. 980-981)

In (17), atár structures the relation between conversational moves and signals the reactivation of a previous discourse segment, temporary deactivated by the digressive move marked by kaitoi 'though, mind you' (Allan 2017b: 292-293). In this case, atár cannot be ascribed any conversational value. Note that the relation with the thematic structure of atár in (17) is by no means comparable to the typical function of the particle in Homer, exemplified in (2), in which atár signals a local thematic discontinuity and introduces a new sentence topic. Rather, this function is partly similar to $(5 \mathrm{a})$ and $(5 \mathrm{~b})$, where atár marks a broader thematic break-off, even though the reactivating function detectable in (17) is not attested in Homer.

In the second place, atár can operate as a DM at the interactional level only. This behavior is attested only once in the corpus, as reported in (18):

(18) N.: apōlómesth' ár', ei kakón prosoísomen neon perish:AOR.M/P.1PL PTC if evil(N):ACC add:FUT.1PL new:ACC.N palaiôi, prìn tód eksēntlèkénai

old:DAT before DEM.ACC.N endure:PF.INF

т.: atàr sú g', ou gàr kairòs eidénai

DM 2SG.NOM PTC not PTC time:NOM know:PF.INF

tóde déspoinan

DEM.ACC.N mistress:ACC

Nurse: 'We will be ruined, if we add new sufferings to the old ones, before ending to suffer from them.'

Tutor: 'But you, it is not the right time for your mistress to know this.' (Eur., Med. 78-81)

In (18), atár occurs turn-initially and links two conversational turns belonging to different speakers, thereby acting at the interactional level only. More specifically, by using atár, speaker в abruptly poses an end to speaker's A turn and fully takes possession of his/her own turn. It is worth observing that, in this case, atár displays a behavior similar to turn-initial allà in its 'correction of discourse topics' function (Drummen 2009: 151). 


\subsection{Summary: a unified account of atár in Classical Greek}

In Attic drama, atár can be described as functioning either as a connective or as a DM. In a handful of occurrences, atár behaves as a connective and establishes coordination relationships of oppositive contrast between two sentences (Mauri 2008). Also, in this function it often correlates with mén. Since atár encodes semantic relationships between SoAs, when behaving as a connective it functions at the representational level of discourse. In most cases, atár rather behaves as a DM and performs different functions at different levels. This is hardly surprising, as polyfunctionality is one of the core features of DMs (Schiffrin 2003). When occurring at the beginning of a turn, as in (18), atár can be described as a turn-taking device that works at the interactional level. When acting as a thematic boundary marker within non-diaphonic monologues, as in (17), atár works at the presentational level. Nevertheless, in a wealth of cases the line between discourse levels seems to be partially blurred, as atár apparently works simultaneously both at the presentational and at the interactional level. On the one hand, atár signals a strong thematic break-off within the speech of an individual character, acting on what Givón (1983: 9) labels 'thematic continuity', as opposed to the narrower 'participant/topic continuity'. On the other hand, it is employed to manage turn-taking and speaker interaction. In this case, it either indicates a speaker's attempt to change the discourse's orientation at the beginning of a new turn after an introductory backgrounded conversational move, as in (8), or it explicitly marks a change of addressee, as in (16). In these occurrences, it is hard to judge which of the two functions is contextually more salient to speakers. In the next section, I argue that this synchronic fuzziness between discourse levels should be interpreted as the by-product of an ongoing process of grammaticalization.

As pointed out in Section 4 and 5, one can detect a variation in the usage of atár between Homeric and Classical Greek. I would like to argue that such a difference can be explained in diachronic terms. To be sure, further investigation on the function of atár in archaic texts other than Homer, and in classical prose texts such as Plato, is needed to provide a more detailed diachronic picture, but some interesting conclusions can be provisionally drawn from the evidence discussed above. It is commonly agreed that sentence connectives can develop a DM function following specific paths of grammaticalization (cf. Traugott 1995, 2010a; Giacalone Ramat \& Mauri 2009; Diewald 2011; see 
Allan 2017a on the grammaticalization of Ancient Greek particles). ${ }^{8}$ Grammaticalization is defined as "the process whereby lexical material in highly constrained pragmatic and morphosyntactic contexts becomes grammatical" (Traugott 1995: 1). With respect to connectives developing into DM, grammaticalization concerns the loss of semantic content, e.g. the encoding of oppositive contrast, and the acquisition of discursive functions. In what follows, I explain how atár might have developed a DM function out of its basic connective value.

In the first place, one needs to account for the shift from connective at the representational level of discourse to DM at the presentational level, a process which had apparently already started in Homer, as hinted by examples (5a) and (5b). The DM function most likely arose in cases of non-prototypical usage of the connective, which can still be detected in Classical Greek, as in (19):

(19) steíkhoim' án; hó ti gàr mè khreốn, go:PRS.OPT.1SG PTC REL.ACC.N INDF.ACC.N PTC NEG need(N):NOM oútoi khreòn patheîn. Atár toi tônd' certainly.not need(N):NOM suffer:AOR.INF CONN PTC DEM.GEN.PL ápoin' hubrismátōn méteisi Diónusós ransom:ACC.PL.N insolency:GEN.PL pay:FUT.3SG Dionysos:NOM se

2SG.ACC

Dionysos: 'I will go, for I cannot suffer what is unnecessary. And as for these insolences, Dionysos will make you pay the price for them.'

(Eur., Bacch. 515-516)

In (19), atár connects two stretches of discourse, and correlates with the introduction of the preverbal contrastive topic tônd' [...] hubrismátōn 'these insolences'. However, a digressive move marked by gàr is inserted between the two utterances connected by atár, which thus performs a reactivating func-

8 Scholars have pointed out how the diachronic processes that give rise to DMs differ from more 'classical' instances of grammaticalization and have suggested the label 'pragmaticalization' instead. I follow Diewald (2011) in considering pragmaticalization an instance of non-canonical grammaticalization (cf. also Allan 2017a). I refer to Giacalone Ramat \& Mauri (2009), Traugott (2010a), Heine (2013), and Degand \& Evers-Vermeul (2015) for further discussion with references. 
tion as well. This is a case of non-prototypical coordination, since one expects coordinated utterances to be at least adjacent in the linear sequence, as Blühdorn (2008: 64-65) points out. In occurrences such as (19), in which backgrounded material is inserted between the coordinated segments, the semantic link between the two may be weakened and atár's context-driven function of thematic boundary marker may be consequently taken over as primary, given its higher saliency in discourse. This is arguably how the connective becomes a DM operating at the presentational level.

In the second place, the development of interactional functions may be explained by taking dialogicity as one of the factors at play. According to Traugott (2010b), dialogic functions of DMs often arise in dialogic contexts, i.e. contexts in which two or more points of view are invoked in discourse. In such contexts, speakers start to use connectives in a speaker-oriented perspective, and exploit their basic function for conversational purposes. The role of dialogicity is more evident within diaphonic monologues, in which the doubling of the voices constitutes a clear index of dialogicity. Example (20) is remarkably instructive in this respect.

(20) étoi philoûsa g' ês húper

indeed love:PRS.PTCP.NOM.F PTC REL.GEN.F over manteúetai, $\quad \bar{e}$ kaí ti sigôs' divine:PRS.M/P.3SG or also INDF.ACC.N keep.silent:PRS.PTCP.NOM.F hôn siōpâsthai khreốn atàr

REL.GEN.PL keep.silent:PRS.INF.M/P need:NOM.N DM thugatròs tês Erekhthéós tí moi daughter(F):GEN ART.GEN.F Erechtheus:GEN INT.ACC 1SG.DAT mélei

care:PRS.3SG

Ion: 'Does she indeed ask for a reply on behalf of a friend, or is she also keeping secret something that must stay hidden? But what do I even care of the daughter of Erechtheus?' (Eur., Ion. 431-434)

In (20), atár introduces an utterance featuring the preverbal topic thugatròs 'of the daughter', thus behaving consistently with its basic connective function. However, the utterance introduced by atár also invokes a different point of view in discourse and can be conceived as question posed by an external character, similar to the diaphonic monologue in (14). Starting from diaphonic contexts such as (20), atár might have been reinterpreted as operating at the interactional level of discourse. This process ultimately leads atár to be used as a full-fledged turn-taking device, as in (18). 
Another source for interactional functions may be traced to instances of topicalization of second person pronouns, as in (21), taken from Homer:

(21) átt', êtoi mèn egò̀n eîm' es pólin, óphra father.voc indeed PTC 1SG.NOM go.PRS.1SG to city.ACC in.order me métēr ópsetai. [...] atàr soí $g^{\prime}$ hôd' 1SG.ACC mother.NOM see.FUT.3SG CONN 2SG.DAT PTC thus epitéllō

order.PRS.1SG

'Father, I will go to the city indeed, so that mother can see me. And to you I command this.' (Hom. Od. 17.9)

In (21), after a digression-here, put into brackets with ellipsis due to its length - the previous discourse is reactivated with a topic shift marked by the occurrence of atàr in conjunction with the second person pronoun soí 'to you'. It seems plausible that from contexts such as (21), in which a second person pronoun is contrastively topicalized, speakers may infer a conversational usage of atár as a marker of change of addressee, which turns out to be more salient in interactional practices. This path also accounts for examples such as (16) above, in which the change of addressee co-occurs with the introduction of a foregrounded move.

Summing up, the cline of this grammaticalization process can be sketched as follows:

connective (representational level) $>$ DM $($ presentational level $)>$ DM (interactional level)

This schema describes how, and in which order, the functions of atár have developed over time. Remarkably, the new functions acquired by atár turn out to follow the subjectification cline proposed by Traugott: "speaker-based, subjective meanings may become salient in certain types of communication as a result of certain interactional practices" (Traugott 2010b). Such a development is also fully supported by similar grammaticalization processes undergone by other Ancient Greek particles, as thoroughly discussed by Allan (2017a). The connective function of atár is prominent in Homeric Greek, although the DM function at the presentational level may have started its development already at this time, as discussed for examples $(5 \mathrm{a})$ and $(5 \mathrm{~b})$. The interactional function, which seems unknown to Homer, is possibly fully achieved only in Classical Greek. To be sure, atár mostly occurs in dialogues already in Homer, but it never shows an interactional value comparable to the one discussed in Section 
5.3.2. and it never appears turn-initially. This provides evidence for the fact that, though source contexts for the subsequent development of atár were possibly already available in Homer, in this phase the grammaticalization of the particle from connective to DM was at most beginning. ${ }^{9}$

Most interestingly, the development of new functions does not entail the loss of the older ones, leading to the situation described in Classical Greek, in which the three functions, viz. connective, DM at the presentational level, and DM at the interactional level, coexist to different extents, as discussed in Section 5.4. This is fully consistent with Diewald's (2001: 377) observation that the so-called 'pragmaticalization' of DMs should be conceived of as a first stage of a grammaticalization process, whereby items undergoing grammaticalization increase their semantic and functional scope without restriction on their structural scope (see Allan 2017a for similar remarks). Therefore, the high frequency of occurrences in which the line between the different functions is blurred can be explained if one assumes that Classical Greek attests to a transitional phase in which atár was still undergoing this grammaticalization process.

The emergence of the collocational patterns discussed in Section 5.3.1, that is, atàr [...] ge and atàr tís, fits well such a diachronic process. The pattern atàr [...] ge is already known to Homer. In Homer, the particle ge emphasizes the contrastiveness of the noun phrase following atár, which can serve either as a sentence topic or as a setting. The expansion of this pattern in Classical Greek is motivated by the new function of atár as a DM. It seems plausible that, having now become a DM marking thematic boundaries, atár starts to strongly correlate with the introduction of new information, which can be emphasized as such by the use of ge, as in (15) above. Instead, the pattern atàr tís is entirely

9 I prefer to describe this variation as the outcome of a diachronic process, rather than as a mere synchronic variation due to stylistic features of the texts employed for the following reasons. First, the absence of an interactional value of atár in Homer cannot be simply ascribed to the lack of proper dialogic contexts, as even in Homer atár virtually occurs only in direct speeches. Thus, if an interactional value was indeed already available, I do not see any plausible stylistic reason for its absence in Homer. Conversely, although the selection of Attic drama as a corpus may partly bias the analysis, the low frequency of atár as a connective in the corpus can be hardly linked to the lack of narrative contexts, as atár is not specifically tied to narratives even in Homer. Again, I find no compelling stylistic reason for this distribution. Finally, it is clear that, even in the case that the variation between Homer and Attic drama is in fact due to stylistic reasons, one still needs to account for the development of the DM functions out of the connective one in the first place. Therefore, not only a diachronic explanation for the polyfunctionality of the particle is needed, but it also fits the distributional patterns observed in the available textual data better. 
unknown to Homer, and its creation must follow the reanalysis of atár as a DM. Functionally, such a relation with interrogative pronouns is fully compatible with the picture outlined so far. Interrogative pronouns and adverbs constitute focal elements of the predication, hence their frequent occurrence after the kind of strong thematic boundaries signaled by atár in Attic drama. In conclusion, in Classical Greek these two collocational patterns of atár increase in frequency as compared to Homeric Greek, on account of the newly created functions of the particle as a presentational and interactional DM.

\section{7}

\section{Conclusions}

In this study, I have provided a description of the usage of atár in Ancient Greek and have shown how its use varies over time, with a focus on Homeric Greek and Attic drama.

In Homer, atár largely behaves as a sentence connective and encodes oppositive contrast at the representational level of discourse. Moreover, it correlates with the introduction of contrastive sentence topics. By contrast, in Attic drama, atár behaves as a foregrounding discourse marker and performs a variety of functions. First, it works at the presentational level of discourse and marks thematic boundaries within conversational turns. Second, it acts at the interactional level and interacts with the turn-taking system. In addition, in a number of cases the line between these functions is rather fuzzy, and atár seemingly acts at both levels.

The functional differences detected between Homeric and Classical Greek can be accounted for in diachronic terms, by postulating a specific path of grammaticalization whereby atár eventually developed conversational values. I have discussed various types of context in which the new functions of atár may have arisen and shown that the direction of the pragmatic change fits well our general understanding of 'pragmaticalization' processes as featuring an increase of subjectivity and of speaker-oriented functions (Traugott 2010b). Notably, the development detected for atár provides further evidence for the existence of a common trend in the grammaticalization of Greek particles such as the one advocated by Allan (2017a). 


\section{References}

Allan, Rutger J. 2014. Changing the topic: topic position in Ancient Greek word order. Mnemosyne 67(2).181-213.

Allan, Rutger J. 2017a. The grammaticalization of Greek particles. Ancient GreekLinguistics. New Approaches, Insights, Perspectives, ed. by Felicia Logozzo \& Paolo Poccetti, 103-118. Berlin/Boston: Mouton de Gruyter.

Allan, Rutger J. 2017b. Ancient Greek adversative particles in contrast. Pragmatic approaches to Latin and Ancient Greek, ed. by Camille Denizot \& Olga Spevak, 273-301. Amsterdam: John Benjamins.

Andorno, Cecilia. 2003. Linguistica testuale. Un'introduzione. Roma: Carocci.

Bain, David. 1977. Actors and audience: a study of asides and related conventions in Greek drama. Oxford: Oxford University Press.

Bakker, Egbert. J. 1993. Boundaries, topics, and the structure of discourse: an investigation of the Ancient Greek particle $\delta \dot{\varepsilon}$. Studies in Language 17.275-311.

Beekes, Robert. 2010. Etymological dictionary of Greek. Leiden: Brill.

Bertrand, Nicolas. 2010. L'ordre de mots chez Homère: structure informationelle, localisation et progression du récit. $\mathrm{PhD}$ dissertation, Université Paris-Sorbonne.

Blakemore, Diana. 2006. Discourse Markers. The handbook of pragmatics, ed. by Laurence Horn \& Gregory Ward, 221-240. Oxford: Oxford University Press.

Blühdorn, Hardarik. 20o8. Subordination and coordination in syntax, semantics and discourse: Evidence from the study of connectives. 'Subordination' versus 'Coordination' in Sentence and Text, ed. by Cathrine Fabricius-Hansen \& Wiebke Ramm, 59-85. Amsterdam/Philadelphia: John Benjamins.

Bonifazi, Anna. 2012. Homer's versicolored fabric: The evocative power of Ancient Greek epic word-making. Washington, DC: Center for Hellenic Studies.

Chantraine, Pierre. 1968. Dictionnaire étymologique de la langue grecque. Paris: Klincksieck.

Crespo, Emilio, Luz Conti \& Helena Maquiera. 2003. Sintax del griego clásico. Madrid: Gredos.

Croft, William. 2003. Typology and universals (2nd ed.). Cambridge: Cambridge University Press.

Degand, Liesbeth \& Jaqueline Evers-Vermeul. 2015. Grammaticalization or pragmaticalization of discourse markers? More than a terminological issue. Journal of Historical Pragmatics 16(1). 59-85.

Denniston, John D. 1954. The Greek particles. Oxford: Oxford University Press.

Diewald, Gabriele. 2011. Pragmaticalization (defined) as grammaticalization of discourse functions. Linguistics 49(2).365-39o.

Dik, Helma. 1995. Word order in Ancient Greek: a pragmatic account of word order variation in Herodotus. Amsterdam: Gieben. 
Dik, Helma. 2007. Word order in Greek tragic dialogue. Oxford: Oxford University Press. Dik, Simon C. 1968. Coordination: its implication for the theory of general linguistics. Amsterdam: North-Holland.

Drummen, Annemieke. 2009. Discourse cohesion in dialogue. Turn-initial $\alpha \lambda \lambda \dot{\alpha}$ in Greek drama. Discourse cohesion in Ancient Greek, ed. by Stephanie J. Bakker \& Gerry Wakker, 135-154. Leiden: Brill.

Duhoux, Yves. 2003. Les particules: une classe des mots à supprimer en grec ancien? Word classes and related topics in Ancient Greek, ed. by Emilio Crespo, Jesus de la Villa \& Antonio R. Revuelta, 519-536. Louvain-la-Neuve: Peeters.

Fedriani, Chiara \& Andrea Sansò. 2017. Pragmatic markers, discourse markers and modal particles. What do we know and where do we go from here? Pragmatic markers, discourse markers and modal particles: New perspectives, ed. by Chiara Fedriani \& Andrea Sansò, 1-33. Amsterdam: John Benjamins.

Giacalone Ramat, Anna \& Caterina Mauri. 20og. Dalla continuità temporale al contrasto: la grammaticalizzazione di tuttavia come connettivo contrastivo. Sintassi storica e sincronica dell'italiano. Subordinazione, coordinazione e giustapposizione, ed. by Angela Ferrari, 449-470. Firenze: Franco Cesati.

Givón, Talmy. 1983. Topic continuity in discourse: An introduction. Topic continuity in discourse: A quantitative cross-language study, ed. by Talmy Givón, 1-45. Amsterdam: John Benjamins.

Gundel, Jeanette K. \& Thorstein Fretheim. 2006. Topic and focus. The handbook of pragmatics, ed. by Laurence Horn \& Gregory Ward, 175-196. Oxford: Oxford University Press.

Guidorizzi, Guido \& Dario del Corno. 1996. Aristofane. Le Nuvole. Milano: Valla.

Halliday, Michael A.K. \& Ruqaiya Hasan. 1976. Cohesion in English. London: Longman. Haspelmath, Martin. 2013. Nominal and verbal conjunction. The world atlas of language structures online, ed. by Matthew S. Dryer \& Martin Haspelmath. Leipzig: Max Planck Institute for Evolutionary Anthropology. Accessed at http://wals.info/ chapter $/ 64$

Heine, Bernd. 2013. On discourse markers: Grammaticalization, pragmaticalization, or something else? Linguistics 51(6).1205-1247.

Horrocks, Geoffrey. 2010. Greek. A history of the language and its speakers (2nd ed.). London: Wiley-Blackwell.

Humbert, Jean. 196o. Syntaxe grecque. Paris: Klincksieck.

Inglese, Guglielmo. 2017. Connettivi testuali: il caso di atár e autár in greco omerico. Ancient Greek Linguistics. New Approaches, Insights, Perspectives, ed. by Felicia Logozzo \& Paolo Poccetti, 155-170. Berlin/Boston: Mouton de Gruyter.

Kroon, Caroline. 1995. Discourse particles in Latin. A study of nam, enim, autem, vero and at. Amsterdam: Gieben.

Levinson, Stephen C. 1983. Pragmatics. Cambridge: Cambridge University Press. 
Lühr, Rosemarie \& Susanne Zeilfelder. 2011. Zur Interdependenz von Diskursrelationen und Konnektoren in indogermanischen Sprachen: Kontrast und Korrektur. Satzverknüpfungen. Zur Interaktion von Form, Bedeutung und Diskursfunktion, ed. by Eva Breindl, Gisella Ferraresi, \& Anna Volodina, 107-148. Berlin: Mouton de Gruyter. Matić, Dejan. 2003. Topic, focus, and discourse structure: Ancient Greek word order. Studies in language 27(3).573-633.

Mauri, Caterina \& Johan van der Auwera. 2012. Connectives. The Cambridge handbook of pragmatics, ed. by Allan Keith \& Kasia M. Jaszczolt, 347-402. Cambridge: Cambridge University Press.

Mauri, Caterina. 2008. Coordination relations in the languages of Europe and beyond. Berlin: Mouton de Gruyter.

Ruijgh, Cornelius. 1957. L'élement achéen dans la langue épique. Assen: Van Gorcum.

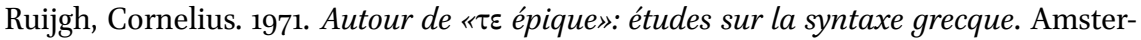
dam: Hakkert.

Sacks, Harvey, Emanuel Schlegoff \& Gail Jefferson. 1974. A simplest systematics for the organization of turn-taking in conversation. Language $5^{\circ .696-735 . ~}$

Schiffrin, Deborah. 2003. Discourse markers: language, meaning, and context. The handbook of discourse analysis, ed. by Deborah Schiffrin, Deborah Tannen \& Heidi E. Hamilton, 54-75. London: Wiley.

Schwyzer, Eduard \& Albert Debrunner. 1950. Griechische Grammatik auf der Grundlage von Karl Brugmanns griechischer Grammatik. Syntax und syntaktische Stilistik. Munich: Beck.

Searle, John R. 1969. Speech acts. Cambridge: Cambridge University Press.

Sidnell, Jack. 2010. Conversation analysis: an introduction. London: Wiley.

Slings, Simon. 1997. Adversative relators between PUSH and POP. New approaches to Greek particles, ed. by Albert Rijksbaron, 101-129. Amsterdam: Gieben.

Sweetser, Eve. 199o. From etymology to pragmatics: metaphorical and cultural aspects of semantic structure. Cambridge: Cambridge University Press.

TLG: Thesaurus linguae Grecae, http://stephanus.tlg.uci.edu/.

Traugott, Elizabeth C. 1995. The role of the development of discourse markers in a theory of grammaticalization. Paper presented at ICHL XII, Manchester 1995.

Traugott, Elizabeth C. 2010a. Grammaticalization. The Bloomsbury companion to historical linguistics, ed. by Silvia Luraghi \& Vit Bubenik, 271-285. London: Bloomsbury.

Traugott, Elizabeth C. 201ob. Dialogic contexts as motivations for syntactic change. Studies in the history of theEnglish Language. Variation and change in English grammar and lexicon, ed. by Robert A. Cloutier, Anne Marie Hamilton-Brehm \& William A. Kretzschmar, 11-27. Berlin: Mouton de Gruyter.

van Emde Boas, Evert. (2017). Analyzing Agamemnon: Conversation analysis and particles in Greek Tragic Dialogue. Classical Philology 112(4).411-434.

van der Auwera, Johan. 2013. Semantic maps, for synchronic and diachronic typology. 
Synchrony and diachrony. A dynamic interface, ed. by Anna Giacalone Ramat, Caterina Mauri \& Piera Molinelli, 153-176. Amsterdam/Philadelphia: John Benjamins.

Viti, Carlotta. 2008. The meaning of coordination in early Indo-European languages. Revue de sémantique et pragmatique $24 \cdot 35^{-64}$.

Willi, Andreas. 2002. The language of Greek comedy: Introduction and bibliographical sketch. The language of Greek comedy, ed. by Andreas Willi, 1-32. Oxford: Oxford University Press. 